\title{
Reconstructing late Neolithic plant economies at the Eastern Adriatic site of Velištak (5th millennium cal BC)
}

\author{
Kelly Reed ', Emil Podrug 2 \\ 1 School of Life Sciences, University of Warwick, UK \\ 2 Šibenik City Museum, Šibenik, HR \\ kellyreed@hotmail.co.uk
}

\begin{abstract}
The archaeobotanical remains from Velištak are the first evidence of plant economies from an open-air settlement dating to the late Neolithic Hvar culture in Croatia (c. 4900-4000 cal BC). The results presented here are from the 2007-2013 field seasons. Based on an examination of carbonised macro-remains, it is suggested that emmer, einkorn, and barley were the main crops at Velištak, along with lentils, bitter vetch, and possibly peas and flax. Wild plants were also exploited, with evidence of wild fruits, such as cornelian cherry. Similarities with archaeobotanical finds from the early/middle Neolithic (c. 6000-4900 cal BC) also suggest that plant economies remained relatively unchanged during the Neolithic.
\end{abstract}

IZVLEČEK - Arheobotanični ostanki z najdišča Velištak predstavljajo prve dokaze o rastlinski ekonomiji iz naselbine na prostem, ki datira v pozni neolitik hvarske kulture na Hrvaškem (ok. 49004000 cal BC). Predstavljeni rezultati so iz podatkov, pridobljenih med izkopavanji med letoma 2007 in 2013. Na podlagi preiskave karboniziranih makroostankov ugotavljamo, da so dvozrnica, enozrnica in ječmen predstavljali glavna žita na Velištaku, navzoči pa so tudi ostanki leče, lečnata grašica ter morda grah in lan. Nabirali so tudi divje rastline, saj so ohranjeni ostanki divjega sadja kot je rumeni dren. Podobnosti z arheobotaničnimi ostanki iz časa zgodnjega in srednjega neolitika (ok. 6000-4900 cal BC) kažejo, da je rastlinska ekonomija na tem območju ostala relativno nespremenjena $v$ celotnem obdobju neolitika.

KEY WORDS - charred macro-remains; cereal cultivation; archaeobotany; Croatia

\section{Introduction}

Archaeological research into the plant economies of the late Neolithic Hvar culture in the Eastern Adriatic is rare. So the discovery of the late Neolithic settlement of Velištak (formerly known as Čista Mala Velištak) in 2007 presented a unique opportunity to examine the development of farming in the Eastern Adriatic, as well as providing the first archaeobotanical results from an open-air Hvar culture village in Croatia (Fig. 1). Hitherto, only two cave sites, Grapčeva (Borojević et al. 2008) and Turska Peć (Reed 2015) in Croatia, and a few grain impressions from daub collected at Lisičići, Herzegovina (Benac 1958.84; Hopf 1958), had provided archaeobotanical evidence of the plant economies of the Hvar culture. However, the social role of caves and the range of activities conducted in them are probably very different from those of open-air settlements (e.g., Bonsall, Tolan Smith 1997; Sampson 2008; Trantalidou et al. 2010). Therefore, this paper presents the archaeobotanical results from the 2007-2013 field seasons at Velištak in order to explore plant exploitation at the settlement more fully, which is important for understanding the development of farming communities in the Eastern Adriatic.

\section{The Eastern Adriatic during the Late Neolithic}

The division of the Neolithic is based on three major pottery stylistic traditions or cultures; Early (Impresso culture, $c$. 6000-5400 cal BC), Middle (Danilo culture, $c .5400-4900 \mathrm{cal} \mathrm{BC}$ ) and Late Neolithic (Hvar culture, $c$. 4900-4000 cal BC). Hvar-style pot- 
tery is decorated with a rich variety of incised and painted designs and is best known from Grapčeva Cave on the island of Hvar (Novak 1955; Forenbaher, Kaiser 2008; Forenbaher et al. 2010). Traces of paint, which would have been applied after firing, indicate that several pigments were used, including red ochre and cinnabar (Forenbaher et al. 2010). So far some 30 Hvar culture sites have been identified, showing that this cultural tradition extended throughout Dalmatia (Croatia) and the hinterlands (Hercegovina). Most of these sites are caves, probably because they are easier to locate than flat open-air settlements.

Research on the Neolithic in the Eastern Adriatic has largely focused around these stylistic and technological changes (e.g., Chapman 1988; Spataro 2002; McClure et al. 2014), while in comparison very little is known about possible underlying socio-economic and cultural shifts.

\section{Evidence of farming in Neolithic Dalmatia}

The first domestic crops and animals, originating from south-west Asia, spread by sea along the coast, reaching Dalmatia at c. $6000 \mathrm{cal} \mathrm{BC}$ (Chapman, Müller 1990; Bogucki 1996; Forenbaher, Miracle 2005; Davison et al. 2006; Forenbaher et al. 2013). Evidence of early farming is limited in Dalmatia, but once established, it would have been an intrinsic part of everyday life during the Neolithic. The earliest indications we have of early Neolithic (c. 6000-5400 cal BC) plant economies in coastal Croatia come from Crno vrilo (Šoštarić 2009), Kargadur (Komšo 2005.21214), Krćina cave (Müller 1994.64), Pokrovnik (Legge, Moore 2011), and Tinj-Podlivade (Huntley 1996). Einkorn (Triticum monococcum ssp. monococcum), emmer (Triticum turgidum ssp. dicoccum), and barley (Hordeum vulgare ssp. vulga$r e$ ) were the most common cereals identified, along with flax (Linum usitatissimum), grass pea (Lathyrus sativus), and a range of wild fruits and weed type species. Similar archaeobotanical evidence has also been recorded for the middle Neolithic (c. 5400-4900 cal BC) sites of Danilo-Bitinj (Hopf 1964; Reed 2006; Legge, Moore 2011), Pokrovnik (Karg, Müller 1990), and Gromače -
Brijuni (Gnirs 1925.24-25). Although limited, these finds suggest that the plant economies did not change drastically in the Eastern Adriatic from the early to the middle Neolithic.

For the late Neolithic (c. 4900-4000 cal BC), plant remains are equally rare, having only been identified from two cave sites in coastal Croatia: Grapčeva (Borojević et al. 2008) and Turska Peć (Reed 2015). At Grapčeva, the evidence consists of a few grains of emmer, einkorn, naked wheat (Triticum cf. aestivum), and lentil (Lens culinaris), as well as shell fragments of almond (Amygdalus communis), acorns (Quercus sp.), and juniper (Juniperus sp.). The naked wheat grain from Grapčeva was also securely radiocarbon dated to 4838-4712 cal BC, confirming its presence during the late Neolithic (Borojević et al. 2008). From Turska Peć, emmer, einkorn, barley, naked wheat (Triticum turgidum ssp. durum/Triticum aestivum ssp. aestivum), possible spelt (Triticum cf. aestivum ssp. spelta), and broomcorn millet (Panicum miliaceum) were identified (Reed 2015). In addition, a large number of weed species were also recovered and are thought to have been associated with episodes of dung burning, possibly to clear the cave of excess waste during seasonal habitation of the cave by herders and livestock (ibid.).

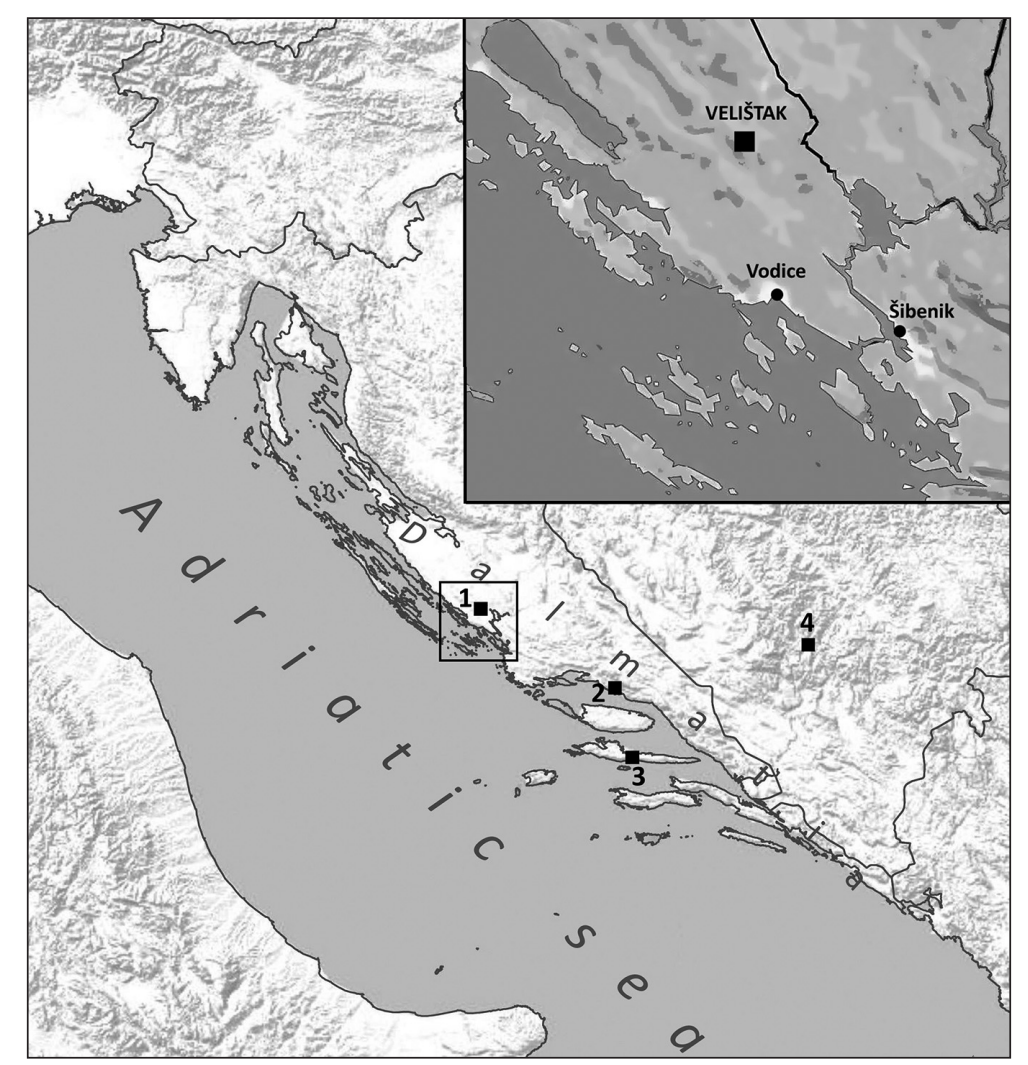

Fig. 1. Late Neolithic sites mentioned in the text: 1 Velištak, 2 Turska Peć, 3 Grapčeva, 4 Lisičići. 
The only exclusively Hvar culture settlement excavated prior to Velištak was at Lisičići (Hercegovina) in the 1950 s, where the only evidence of plant remains came from grain impressions found in daub fragments. These were only briefly listed as wheat, barley, and rye (Benac 1958.84; Hopf 1958), although it is likely that the rye was a

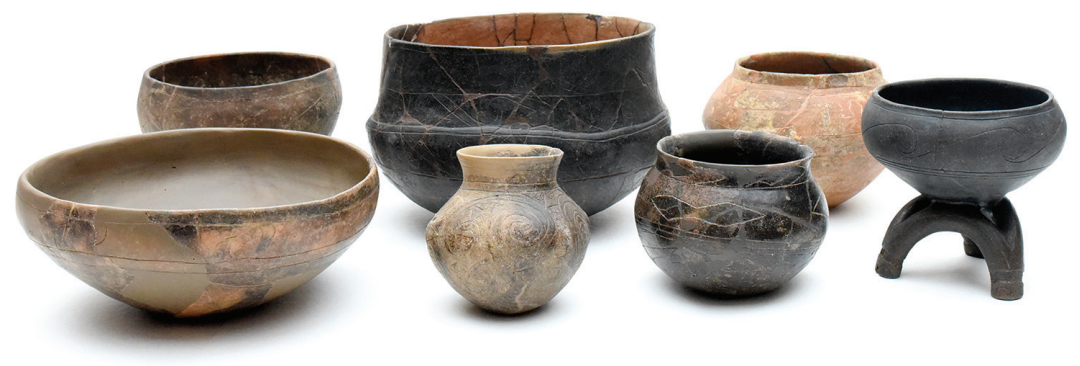

Fig. 2. Pottery of the 'Outlined' Hvar style from Velištak. weed, as evidence suggests that rye was not grown as a crop until at least the Iron Age (Behre 1992).

Zooarchaeological studies of Neolithic assemblages in the Eastern Adriatic have also demonstrated the predominance of domesticated species such as cattle, ovicaprids, and pig (Miracle, Forenbaher 2005; Moore et al. 2007a; 2007b; Legge, Moore 2011). Sites such as Pokrovnik and Danilo-Bitinj suggest that hunting played a minor role in subsistence during the early and middle Neolithic (Moore et al. 2007a; 2007b; Legge, Moore 2011), while stable isotope studies of early Neolithic human remains suggest that marine resources were also consumed by some individuals during this time (Lightfoot et al. 2011). Stable isotope studies on animal remains have also provided information about animal management strategies, suggesting that pig management changed during the Neolithic, possibly through different foddering practices, while in contrast, cattle and ovicaprid management remained unchanged (Zavodny et al. 2014).

\section{The case study}

The archaeological site of Velištak is situated in the Velim Valley to the north of Vodice in northern Dalmatia, Croatia (Fig. 1). The site was discovered in 2007 during agricultural work, and excavations subsequently were begun in the same year by Emil Podrug of Šibenik Municipal Museum (Podrug 2010; 2014). The excavations are continuing, but after nine excavation campaigns (2007-2015), an area of $335 \mathrm{~m}^{2}$ has been opened. A large quantity of classic Hvar culture pottery has been recovered (Fig. 2), along with tools made of animal bone, knapped and polished stone, as well as jewellery and polished shells (Spondylus gaederopus) (Podrug 2010; 2013). The Velištak pottery corresponds to the initial 'Outlined' decorative stage (e.g., sub-phase 1.1 of Grapčeva -'bordered' classic Hvar) (Forenbaher, Kaiser 2008.51-52). This is supported by six radiocarbon dates that show the settlement was founded sometime after $5000 \mathrm{cal} \mathrm{BC}$ and lasted until 4700 cal BC (McClure et al. 2014.1027, T.1), making Velištak the earliest known Hvar culture site.

At the subsoil level, numerous pits and other dugout features have been revealed, often intersecting each other, suggesting that they were not all dug and used at the same time (Fig. 3). Most of the pits are round or oval in plan and cylindrical or spherical in shape, and it is suggested that some were probably used for grain storage (Podrug 2013). The pits were usually filled with pottery and animal bones, which, along with numerous layers of soot and ash,

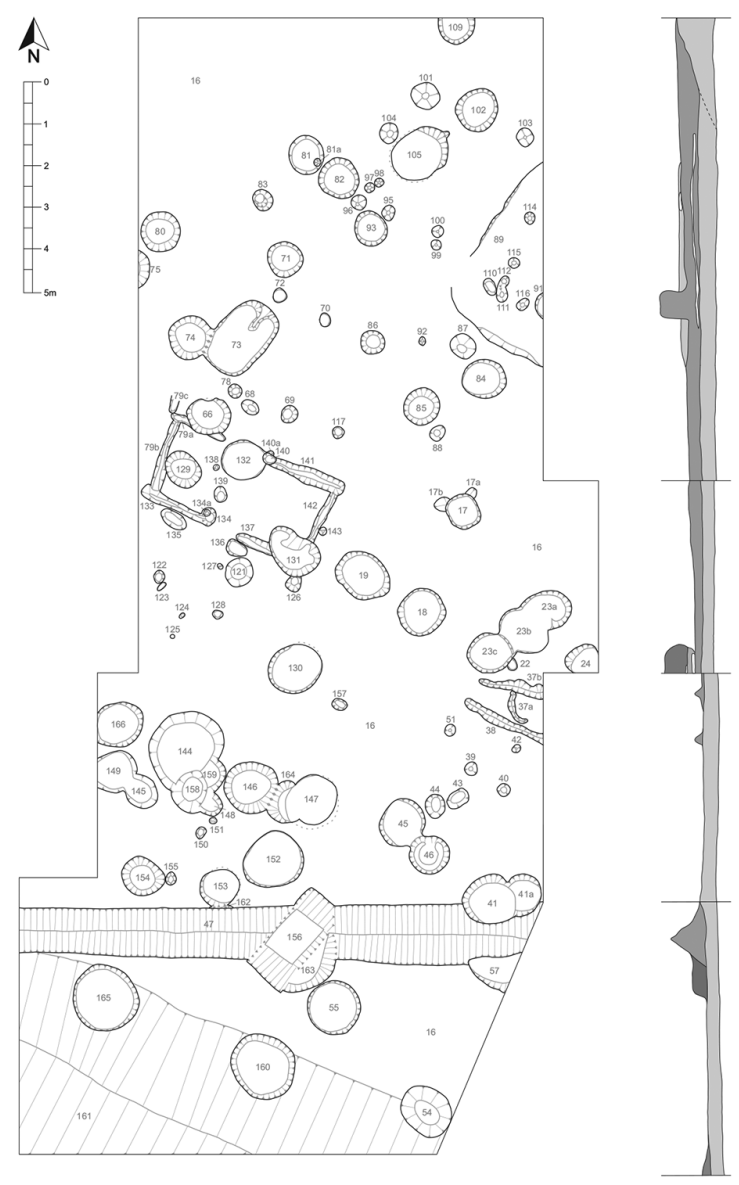

Fig. 3. Plan of the excavated area at the subsoil level and the eastern profile at Velištak. 
suggest that the pits were eventually used as disposal places for household refuse and other communal waste (ibid.). Several fragments of house floors, fireplaces and hearths are also present in undisturbed general cultural layers (in the northern part of the excavation area, these layers are preserved up to $60 \mathrm{~cm}$ in thickness). Overall, the stratigraphy at Velištak shows continuous successive occupation at the settlement over several generations.

\section{Material and methods}

During 2007-2013, 52 samples were collected from 24 contexts relating to house floors, pits and fireplaces from trenches A to F (Tab. 1). A total of 52 samples were collected, totalling 571.5 litres of sediment, and processed through bucket flotation using $1 \mathrm{~mm}$ and $250 \mu \mathrm{m}$ mesh sizes.

The plant taxa were established with a low resolution (7-40x) binocular microscope and comparisons made from the modern reference collections at the School of Archaeology and Ancient History at the University of Leicester. The nomenclature of scientific plant names for cultivars follows Daniel Zohary et alii (2012) and for wild plants Tom G. Tutin et alii (1964-1980). All floats were $100 \%$ sorted and the charcoal volumes recorded. A standardised counting method was used, whereby each grain counts as one and the whole grain equivalent (WGE) was estimated for fragments of grains. Glume base fragments were counted as one unless clearly representing part of another fragment, while whole spikelet forks were counted as two glume bases. The fruit and weed seeds were counted as one, even when only a fragment was found, except when large seeds were broken and the parts were clearly from the same seed (e.g., Cornus mas).

\section{Results}

Carbonised plant remains were recovered from 45 of the 52 samples, as well as two mineralised seeds of Buglossoides from samples 34 and 62. A total of 3491 seeds were identified, with a further 973 indeterminate plant items. Seed density was particularly low, with 37 samples having a density of less than 1 seed per litre of sediment (Tab. 1, Fig. 4). The two samples with the highest density were 184 and 185 , both from the same lower half of a pit fill, with a seed density of 16.7 and 93.5, respectively. Charcoal density was also low, with all the samples having less than $2.0 \mathrm{~cm}^{3}$ per litre.

\section{Crops}

Cereals were the most commonly recovered plant remains at the site, accounting for $94 \%$ of the identified assemblage, not including cereal fragments and indeterminate remains (Fig. 5). Of the cereal grains, $93 \%$ of the remains were of barley (Hordeum vulgare ssp. vulgare), totalling 879 grains, although 838 of these were recovered from samples 184 and 185 (Fig. 6).

In addition, 19 grains of emmer (Triticum turgidum $L$. ssp. dicoccum), 18 grains of 1-grained einkorn (Triticum monococcum L. ssp. monococcum), 1 grain of 2-grained einkorn (for identification criteria see Kroll 1992; Kreuz, Boenke 2002) and 1 grain of naked wheat (similar to Triticum aestivum $L$. ssp. compactum) (Tab. 2) were recovered. A large

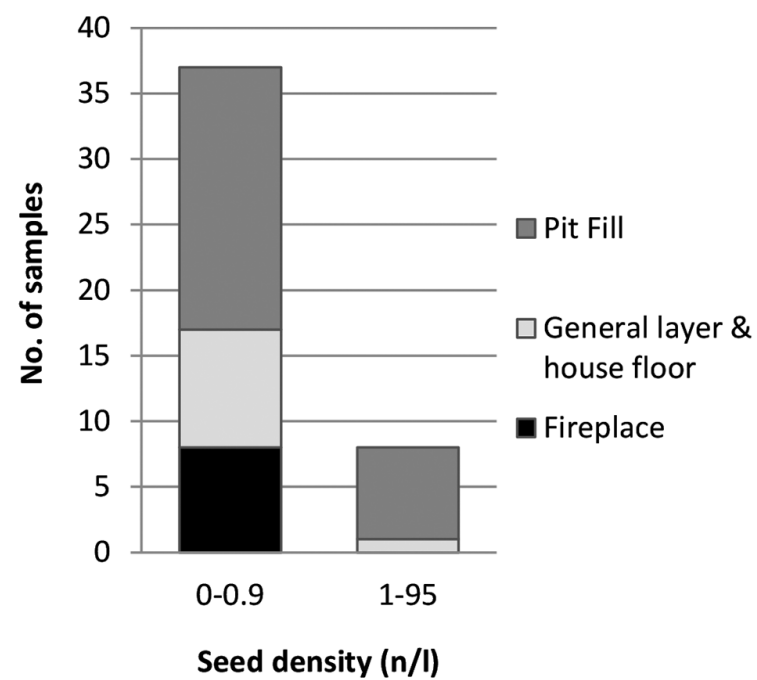

Fig. 4. Seed density (n/l) per sample per context type at Velištak.

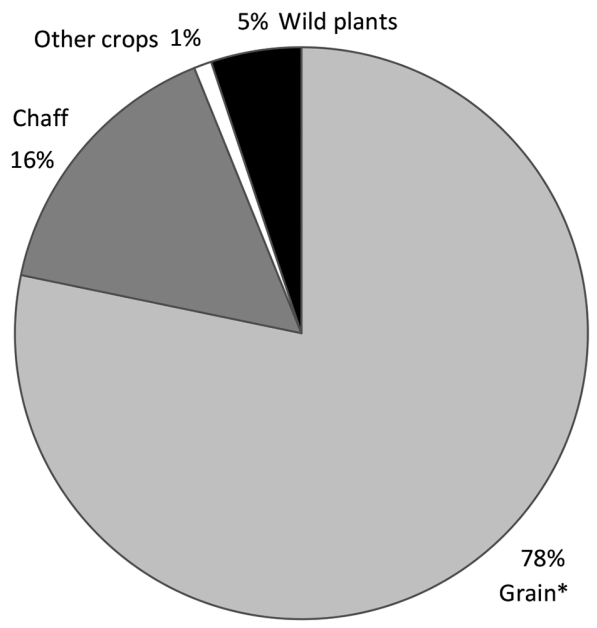

Fig. 5. Composition of the carbonised plant assemblage per plant category at Velištak. *Not including cerealia fragments. 
number of fragmented cereal remains were also recovered from samples 179,184 and 185, which are all from the same pit feature, totalling approx. 1225 grain fragments (Tabs. 1-2).

Cereal chaff (cereal husk separated by winnowing and/or threshing), which accounts for $16 \%$ of the assemblage, is dominated by glume wheat glume bases. Preservation was particularly poor, but where possible, einkorn, emmer and the "newtype' glume wheat were identified, although in low numbers (Tab. 2). The identification of the 'new type' of glume wheat glume base was based on observations made by Glynis Jones et alii (2000) and Marianne Kohler-Schneider (2003) and stood out, as they were more 'robust' than the emmer and einkorn glume bases.

A small number of other crops were also identified from pit samples, including four lentils (Lens culinaris), two possible peas (Pisum sp.), one bitter vetch (Vicia ervilia) and two possible flax seeds (Linum sp.) (Tab. $3)$.

\section{Wild plants}

Wild plants make up 5\% of the assemblage, and consist of fruit remains, possible weed species and other wild plants (Fig. 4; Tab. 3). Of the fruits, only one cornelian cherry (Cornus mas), one rose hip (Rosa canina), and one bramble fruit seed (Rubus sp.), as well as two acorn fragments (Quercus sp.) were identified within four samples taken from pits (Tabs. 1, 3). Due to poor preservation, the vast majority of the wild plant remains are identified only to family or genus, with the highest number of remains being identified as either large-seeded legumes (Fabacaeae) or large- and small-seeded grasses (Poaceae) (Tab. 3).

\begin{tabular}{|c|c|c|c|c|c|c|}
\hline $\begin{array}{l}\text { Sample } \\
\text { no. }\end{array}$ & Trench & $\begin{array}{c}\text { Stratigraphic } \\
\text { unit } \\
\text { (S)) }\end{array}$ & $\begin{array}{c}\text { Feature } \\
\text { type }\end{array}$ & $\begin{array}{c}\text { Sample } \\
\text { vol. } \\
\text { (I) }\end{array}$ & $\begin{array}{l}\text { Seed } \\
\text { density } \\
(n / l)\end{array}$ & $\begin{array}{c}\text { Charcoal } \\
\text { density } \\
\left(\mathrm{cm}^{3} / \mathrm{l}\right)\end{array}$ \\
\hline 16 & A & 3 & General layer & 9 & 0.6 & 1.1 \\
\hline 19 & A & 3 & General layer & 6.5 & 0.5 & 1.5 \\
\hline 22 & A & 3 & General layer & 7 & - & 0.4 \\
\hline 25 & A & $19-1$ & Pit Fill & 5 & 0.6 & 1.0 \\
\hline 26 & $\mathrm{~A}$ & $3 \& 14$ & Fireplace & 6 & 0.0 & 0.5 \\
\hline 30 & $\bar{A}$ & $17-1$ & Pit Fill & 7 & 0.7 & 0.3 \\
\hline 34 & A & $18-1$ & Pit Fill & 6.5 & 3.1 & 2.0 \\
\hline 37 & A & $23-1$ & Pit Fill & 5 & 0.2 & 0.8 \\
\hline 41 & A & 3 & General layer & 5.5 & 0.2 & 1.1 \\
\hline 44 & A & 14 & Fireplace & 8 & 0.2 & 0.4 \\
\hline 48 & A & 20 & Fireplace & 5 & 0.1 & 0.2 \\
\hline 49 & $\mathrm{~A}$ & $23-1$ \& 23-2 & Pit Fill & 5 & 11.0 & 2.0 \\
\hline 50 & $\mathrm{~A}$ & $24-1$ & Fireplace & 4 & 0.2 & 0.1 \\
\hline 61 & A & $24-2$ & Pit Fill & 7 & 0.3 & 0.9 \\
\hline 62 & A & $24-3$ & Fireplace in a pit & 5 & 0.1 & 0.2 \\
\hline 63 & B & 3 & General layer & 7 & 0.4 & 0.7 \\
\hline 70 & $\mathrm{~A}$ & $24-4$ & Pit Fill & 3.5 & - & 1.7 \\
\hline 72 & $\mathrm{~B}$ & 3 & General layer & 5 & 2.4 & 2.0 \\
\hline 84 & $\mathrm{~B}$ & $24-4$ & Pot fill in pit & 2.5 & 0.0 & 0.2 \\
\hline 90 & $\mathrm{C}$ & 46-1 & Fireplace in pit & 6 & - & 0.1 \\
\hline 91 & $\mathrm{C}$ & $46-3$ & Fireplace in pit & 7 & 0.2 & 0.1 \\
\hline 92 & $\mathrm{C}$ & $46-3$ & Fireplace in pit & 7 & 0.4 & 0.1 \\
\hline 93 & C & $45-1$ & Pit fill & 7 & 0.2 & 0.3 \\
\hline 94 & $\mathrm{C}$ & $45-1$ & Pit fill & 10 & 0.3 & 0.2 \\
\hline 97 & $\mathrm{C}$ & $46-6$ & Pit fill & 8 & 0.3 & 0.4 \\
\hline 98 & $\mathrm{C}$ & $46-6$ & Pit fill & 6 & 0.3 & 0.1 \\
\hline 110 & $\mathrm{D}$ & $57-1$ & Pit fill & 13 & 0.1 & 0.2 \\
\hline 111 & $\mathrm{D}$ & $57-1$ & Pit fill & 10 & 0.1 & 0.1 \\
\hline 112 & D & $41-2$ to $41-8$ & $\begin{array}{l}\text { Fireplaces } \\
\text { in pit }\end{array}$ & 10 & - & 0.1 \\
\hline 117 & D & $41-2$ to $41-4$ & $\begin{array}{c}\text { Fireplaces } \\
\text { in pit }\end{array}$ & 16 & 0.5 & 0.2 \\
\hline 118 & $\mathrm{D}$ & $41-9$ & Pit fill & 13 & 0.6 & 1.2 \\
\hline 119 & $\mathrm{D}$ & $41-9$ & Pit fill & 19 & 0.7 & 0.4 \\
\hline 121 & $\mathrm{D}$ & $41-10$ & Pit fill & 14 & 0.1 & 0.1 \\
\hline 122 & $\mathrm{D}$ & $41-10$ & Pit fill & 12 & 0.3 & 0.1 \\
\hline 177 & $\mathrm{~F}$ & $3-1$ & General layer & 17 & 0.5 & 0.2 \\
\hline 178 & $\mathrm{~F}$ & $3-1$ & General layer & 19 & 0.5 & 0.3 \\
\hline 179 & $\mathrm{~F}$ & $73-1$ & it (upper half of fill) & 21 & 7.6 & 0.6 \\
\hline 180 & $\mathrm{~F}$ & $73-1$ & it (upper half of fill) & 17 & 3.2 & 0.4 \\
\hline 184 & $\mathrm{~F}$ & $73-1$ & it (lower half of fill) & 18 & 16.7 & 0.9 \\
\hline 185 & $\mathrm{~F}$ & 73-1 & it (lower half of fill) & 19 & 93.5 & 1.1 \\
\hline 193 & $\mathrm{~F}$ & 74-1 & Pit fill & 20 & 0.4 & 0.8 \\
\hline 194 & $\mathrm{~F}$ & 74-1 & Pit fill & 19 & 0.2 & 0.4 \\
\hline 216 & B-E & $84-1$ & Pit fill & 13 & 0.7 & 0.2 \\
\hline 218 & B-E & $3-1$ & General layer & 17 & 0.1 & 0.1 \\
\hline 219 & B-E & $3-1$ & General layer & 16 & - & 0.0 \\
\hline 221 & B-E & $85-1$ & Pit fill & 13 & 0.3 & 0.1 \\
\hline 238 & B-E & 3-1 & General layer & 17 & - & 0.0 \\
\hline 239 & B-E & $3-1$ & General layer & 15 & - & 0.0 \\
\hline 249 & B-E & 3 \& 106 & $\begin{array}{c}\text { General layer }+ \\
\text { house floor }\end{array}$ & 18 & 0.2 & 0.0 \\
\hline 250 & B-E & 106 \& ו-3 & $\begin{array}{c}\text { General layer }+ \\
\text { house floor }\end{array}$ & 18 & 0.2 & 0.0 \\
\hline 258 & B-E & $105-6$ & Pit fill & 13 & 5.4 & 0.8 \\
\hline 259 & B-E & $105-6$ & Pit fill & 14 & 0.8 & 0.4 \\
\hline
\end{tabular}

Tab. 1. Summary table of charcoal and seed densities/l for each sample at Velištak. 


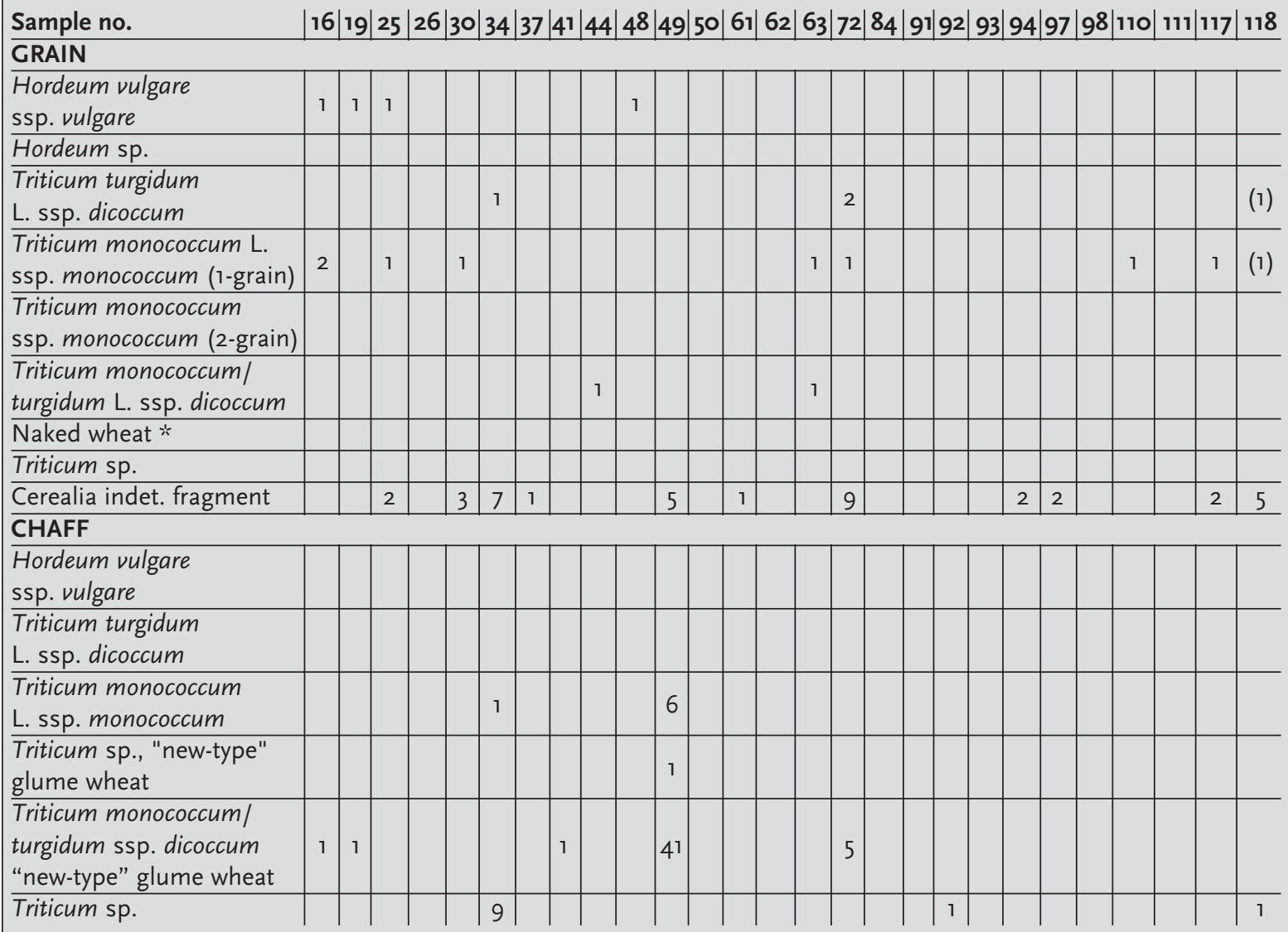

\begin{tabular}{|c|c|c|c|c|c|c|c|c|c|c|c|c|c|c|c|c|c|c|c|}
\hline \multirow{2}{*}{$\begin{array}{l}\text { Sample no. } \\
\text { GRAIN }\end{array}$} & \multicolumn{3}{|c|}{ | $119|121| 122$} & \multicolumn{2}{|c|}{\begin{tabular}{|l|l|}
177 & 178 \\
\end{tabular}} & \multicolumn{3}{|c|}{\begin{tabular}{|l|l|l|}
179 & 180 & 184 \\
\end{tabular}} & \multicolumn{3}{|c|}{\begin{tabular}{|l|l|l|}
185 & 193 & 194 \\
\end{tabular}} & \multicolumn{2}{|c|}{\begin{tabular}{|l|l|}
216 & 218 \\
\end{tabular}} & \multirow[t]{2}{*}{221} & \multirow{2}{*}{\multicolumn{2}{|c|}{$|249| 250$}} & \multirow[t]{2}{*}{258} & \multicolumn{2}{|c|}{ |259|TOTAL } \\
\hline & & & & & & & & & & & & & & & & & & & \\
\hline $\begin{array}{l}\text { Hordeum vulgare } \\
\text { ssp. vulgare }\end{array}$ & 3 & 1 & & & 3 & 12 & 13 & $\begin{array}{c}76 \\
(10)\end{array}$ & 752 & 1 & & 2 & 1 & & & & 1 & & $\begin{array}{l}869 \\
(10) \\
\end{array}$ \\
\hline Hordeum sp. & & & & 1 & & & & & & & & & & & & & & 1 & 2 \\
\hline $\begin{array}{l}\text { Triticum turgidum } \\
\text { L. ssp. dicoccum }\end{array}$ & & & & (2) & & 1 & & & 9 & & 1 & & 1 & & & & 1 & & $16(3)$ \\
\hline $\begin{array}{l}\text { Triticum monococcum L. } \\
\text { ssp. monococcum (1-grain) }\end{array}$ & & & 1 & & 1 & & & & 2 & 2 & & & & & & & $\begin{array}{c}1 \\
(2) \\
\end{array}$ & & $15(3)$ \\
\hline $\begin{array}{l}\text { Triticum monococcum } \\
\text { ssp. monococcum (2-grain) }\end{array}$ & & & & & & & 1 & & & & & & & & & & & & 1 \\
\hline $\begin{array}{l}\text { Triticum monococcum/ } \\
\text { turgidum L. ssp. dicoccum }\end{array}$ & & & & & 1 & & & & & & & & & 2 & & & & & 5 \\
\hline Naked wheat * & & & & & & & & 1 & & & & & & & & & & & 1 \\
\hline Triticum sp. & & & & & & 3 & & & & & & 1 & & & 1 & & 1 & 5 & 11 \\
\hline Cerealia indet. fragment & 3 & & & 1 & 3 & 69 & 17 & 156 & 1000 & & 2 & 5 & & 4 & 2 & 2 & 13 & 6 & 1322 \\
\hline CHAFF & & & & & & & & & & & & & & & & & & & \\
\hline $\begin{array}{l}\text { Hordeum vulgare } \\
\text { ssp. vulgare }\end{array}$ & & & & & & & & & 1 & & & & & & & & & & 1 \\
\hline $\begin{array}{l}\text { Triticum turgidum } \\
\text { L. ssp. dicoccum }\end{array}$ & & & & & & & & 3 & & 1 & & & & & & & & & 4 \\
\hline $\begin{array}{l}\text { Triticum monococcum } \\
\text { L. ssp. monococcum }\end{array}$ & & & & & & 2 & & 2 & & & & & & & & & & & 11 \\
\hline $\begin{array}{l}\text { Triticum sp., "new-type" } \\
\text { glume wheat }\end{array}$ & & & & & & & & & & & (1) & & & & & & & & 1 (1) \\
\hline $\begin{array}{l}\text { Triticum monococcum/ } \\
\text { turgidum ssp. dicoccum } \\
\text { "new-type" glume wheat }\end{array}$ & & & & & & & & & & & & & & & & & & & 49 \\
\hline Triticum sp. & & & & & & 5 & 1 & 27 & & 4 & & & & & & & 72 & & 120 \\
\hline
\end{tabular}

Tab. 2. The total number of cereal items (inc. whole grain equivalents, WGE) per sample at Velištak. (n) $=c f$; * Naked wheat $=$ Triticum turgidum ssp. durum/Triticum aestivum. 


\section{Discussion}

\section{Formation processes}

In order to understand the archaeobotanical results, it is important to explore the formation processes at the site in order to identify any possible bias in the samples that may influence interpretations. The most common form of preservation at Velištak was carbonisation or charring, which results from organic material being exposed to heat either accidentally or deliberately, such as cooking, burning rubbish or fuel (Hillman 1984; Miller, Smart 1984; Charles 1998; Valamoti, Charles 2005; Van der Veen 2007). Thus, carbonised plant remains will be heavily biased towards items that come into contact with fire more frequently and survive the charring process (Dennell 1972; Hillman 1981; Jones 1981; Boardman, Jones 1990; Van der Veen 2007).

The deposition of these remains within the archaeological record also needs to be considered. For example, Richard N. L. B. Hubbard and Alan J. Clapham (1992) suggested that charred assemblages can be divided into three groups: Class A, where remains have been burnt within the context within which they are recovered; Class $\mathrm{B}$, where an assemblage derives from one burning event that was subsequently moved to the context (secondary deposition); and Class $\mathrm{C}$, where the assemblage derives from different charring events that were subsequently deposited within the same context. Seed density has also been used to reflect the rate of deposition, whereby a low density of plant remains indicates slow accumulation, while high densities suggest rapid deposition (Jones 1991).

At Velištak, seed density was particularly low, with 37 samples having a density of less than 1 seed per litre of sediment (Fig. 4). In addition, only ten samples were collected from a fireplace or area where burning occurred and only a few seeds were recovered. The remaining contexts and the overall low seed and charcoal densities of the samples suggests that the remains probably reflect Class $C$ assemblages, which derive from different charring events that were subsequently deposited within a secondary or even tertiary context. The only exceptions to this are the two samples with particularly high densities, 184 and 185, which were both from the same lower half of a pit fill. Both are dominated by barley grains, although poor preservation led to a high number of grains being identified as 'cerealia' fragments. The samples also contain a small number of wheat grains and chaff, a few pulses and a handful

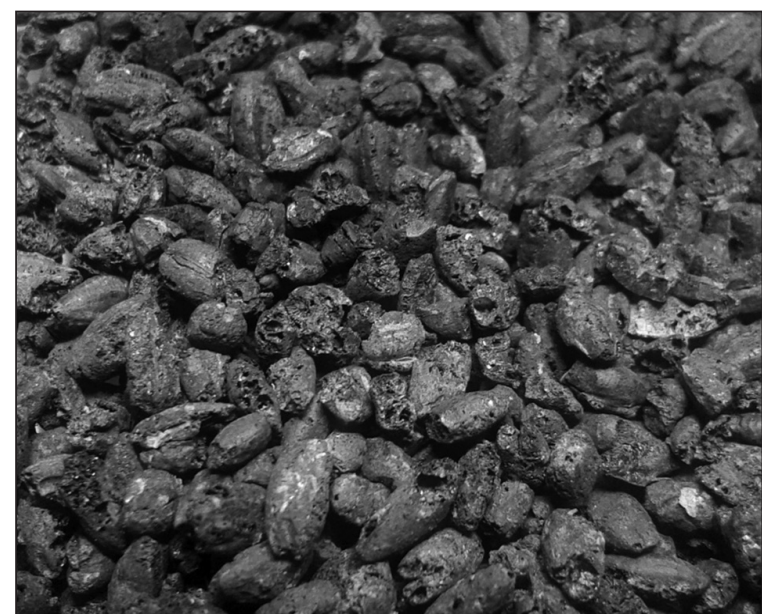

Fig. 6. Barley grains (Hordeum vulgare ssp. vulgare), sample no. 185.

of weeds. In contrast, samples 179 and 180 from the upper half of the same pit contain only a small number of barley grains $(<13)$. These differences may suggest that the charred plant remains at the bottom of the pit were deposited more intensively, as part of one activity, or more rapidly, from a number of activities, than at the top of the pit.

But what activities might these plant remains represent at Velištak? Since the 1970s researchers have determined that carbonised remains are more likely to result from food production processing, e.g., crop processing, rather than food consumption (Knörzer 1971; Dennell 1972; 1974; 1976; Hillman 1984; Jones 1984). Predictive models have since been created to identify which stage of the crop processing sequence an assemblage represents, based on the assumption that each stage produces a characteristically different ratio of cereal, chaff and weeds within the sample (Hillman 1984; Jones 1984; Van der Veen 1992; Van der Veen, Jones 2006).

The general uniform composition of the assemblage at Velištak of cereal grains, chaff and weeds would suggest that the remains represent harvested cereals. Overall, the low seed density makes it difficult to apply any of the predictive models, as over 50 seeds per sample are required for a meaningful result (e.g., Bogaard 2004.63). Only four samples (nos. $179,184,185,258$ ) have over 50 plant items, although sample no. 179 is dominated by cereal fragments. The dominance of barley grain within sample nos. 184 and 185 and their high density within the context may suggest that these samples represent a deposit of a barley crop. In contrast, sample no. 258 , which is from a pit a few metres away, has a high proportion of glume wheat glume bases and 
no weed remains. This sample may therefore represent the dehusking of cleaned glume wheats (Reed 2015). Some suggest that the daily processing of stored glume wheats occurred within the household, where the waste (cereal chaff) was then swept into fires and carbonised (cf. Hillman 1984; Gregg 1989; Meurers-Balke, Lüning 1992; Bogaard 2004.68; Kreuz 2012). The waste from these fires may have then been deposited outside the house, and so sample no. 258 may indicate the secondary or tertiary deposition of discarded wheat chaff. Archaeological finds of querns and flint sickle blades also attest to crop processing activities at Velištak. However, the recovery of only one barley rachis at the site may suggest that either barley was mainly processed away from the settlement or that the more fragile barley rachis did not survive the carbonisation process (cf. Dennell 1976; Hillman 1981; Boardman, Jones 1990).

\section{The importance of barley}

Barley is one of the principle crops that spread with farming and as such is found in varying quantities throughout the Neolithic in south-east Europe. In Albania (e.g., Xhuveli, Schultze-Motel 1995; Gjipali, Allen 2013), Bosnia and Herzegovina (e.g., Hopf 1958; 1966/7; Renfrew 1979; Kučan 2009), Serbia (Filipović, Obradović 2013 for summary), Slovenia (e.g., Tolar et al. 2011), and Italy (e.g., Robb 2007. 129-131; Rottoli, Pessina 2007; Rottoli, Castiglioni 2009) hulled and naked six-rowed varieties have been recovered along with emmer and einkorn. In Hungary, the late Neolithic settlement of BattonyaParázstanya has the largest number of naked barley grains, totalling 2792 (Gyulai 2010).

There are advantages and disadvantages to growing both naked and hulled barley. In terms of crop processing, naked barley is easier to process, as the grain is looser in the spikelets and can be easily threshed, while hulled barley requires an extra crop processing stage to release the grain from the tighter chaff. On the other hand, it has been suggested that hulled barley has a greater tolerance to adverse environmental conditions (e.g., soil salinity, parasites) (Ceccarelli et al. 2001; Lister, Jones 2013), while it has been suggested that naked barley grains are

\begin{tabular}{|c|c|c|c|c|c|c|c|c|c|c|c|c|c|c|c|c|c|c|c|}
\hline \multirow{2}{*}{$\begin{array}{l}\text { Sample no. } \\
\text { OTHER CROPS }\end{array}$} & \multicolumn{19}{|c|}{ 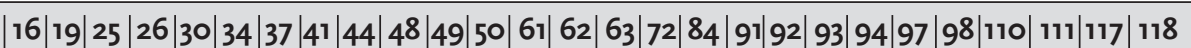 } \\
\hline & & & & & & & & & & & & & & & & & & & \\
\hline Lens culinaris & & & & & & & & & & & & & & & & & 1 & (1) & \\
\hline Pisum sp. & & & & & & & & & & & & & & & & & & & \\
\hline Vicia ervilia & & & & & & & & & & & & & & & & & & & \\
\hline Linum sp. & & & & & & & & & & & & & & & & & & & \\
\hline WILD PLANTS & & & & & & & & & & & & & & & & & & & \\
\hline Asteraceae & & & & & & & & & & 1 & & & & & & & & & \\
\hline cf. Avena sp. & & & & & & & & & 1 & & & & & & & & & & \\
\hline Buglossoides (mineralised) & & & & & 1 & & & & & & & 1 & & & & & & & \\
\hline Chenopodium album & & & & & & & & & & & & & & & & & & & \\
\hline Chenopodium sp. & & & & & & & & & & & & & & & & & & & \\
\hline Cornus mas & & & & & & & & & & & & & & & & & & & \\
\hline Fabaceae (large) & & & & & & & & & & & & & & & 1 & 1 & 1 & & \\
\hline Fabaceae (small) & & & & & & & & & & & & & & & & & & & \\
\hline Galium sp. & 1 & & & & & & & & & & & & & & & & & & \\
\hline Lolium sp. & & & & & & & & & & & & & & & & & & & \\
\hline Lolium temulentum & & & & & & & & & & & & & & & & & & & \\
\hline Phleum sp. & & & & & & & & & & & & & & & & & & & \\
\hline Poaceae (large) & & & & & 2 & & & & & & & & & 1 & i & & & & \\
\hline Poaceae (small) & & & & & & & & & 1 & & & & & & & & & & \\
\hline cf. Polygonum sp. & & & & & & & & & & & & & & & & & & & \\
\hline Quercus sp. & & & & & & & & & & & & & & & & & & & \\
\hline Rosa canina & & & & & & & & & & & & & & & & & & & \\
\hline Rubus sp. & & & & & & & & & & & & & & & & & & & \\
\hline Rumex sp. & & & & & 1 & & & & & & & & & & & & & & \\
\hline Sambucus ebulus & & & & & & & & & & & & & & & & & & & \\
\hline Teucrium sp. & & & & & & & & & & & & & & & & & & & \\
\hline Verbascum sp. & & & & & & & & & & & & & & & & & & & \\
\hline Indeterminate fruit & & & & & & & & & & & & & & & & & & & \\
\hline Indeterminate & 26 & \begin{tabular}{|l|l|l|}
5 & 10 & 12
\end{tabular} & \begin{tabular}{l|l}
2 & 3 \\
\end{tabular} & \begin{tabular}{|l|l|}
3 & 1
\end{tabular} & $|18|$ & \begin{tabular}{|l|l|}
3 & 9
\end{tabular} & 9 & 5 & $\mid 56$ & & 4 & & \begin{tabular}{|c|c|} 
& \\
\end{tabular} & 3 & & & & & \\
\hline
\end{tabular}

Tab. 3. The total number of other crops and wild plants per sample at Velištak. (n) =cf. 


\begin{tabular}{|c|c|c|c|c|c|c|c|c|c|c|c|c|c|c|c|c|c|c|}
\hline \multirow{2}{*}{$\begin{array}{l}\text { Sample no. } \\
\text { OTHER CROPS }\end{array}$} & \multicolumn{2}{|c|}{\begin{tabular}{|l|l|l|l|} 
& 119 & 121 & 122
\end{tabular}} & $\mid 177$ & 178 & \multicolumn{3}{|c|}{$179|180| 184 \mid$} & \multicolumn{2}{|c|}{$|185| 193$} & 194 & \multicolumn{2}{|c|}{$|216| 218 \mid$} & |221 & \multicolumn{3}{|c|}{\begin{tabular}{|l|l|l|}
249 & 250 & 258
\end{tabular}} & \multicolumn{2}{|c|}{ |259|TOTAL } \\
\hline & & & & & & & & & & & & & & & & & & \\
\hline Lens culinaris & & & & & & & 2 & 1 & & & & & & & & & & $4(1)$ \\
\hline Pisum sp. & & & & & & & & 2 & & & & & & & & & & 2 \\
\hline Vicia ervilia & & & & & & & 1 & (3) & & & & & & & & & & $1(3)$ \\
\hline Linum sp. & 1 & & & & & & & (1) & & & & & & & & & & 1 (1) \\
\hline WILD PLANTS & & & & & & & & & & & & & & & & & & \\
\hline Asteraceae & & & & & & & & & & & & & & & & & & 1 \\
\hline cf. Avena sp. & & & & & & & & & & & & & & & & & & 1 \\
\hline Buglossoides (mineralised) & & & & & & & & & & & & & & & & & & 2 \\
\hline Chenopodium album & & & 1 & & & & & & & & & & & & & & & 1 \\
\hline Chenopodium sp. & & & & & & 1 & & & & & & & & & & & & 1 \\
\hline Cornus mas & & & & & & & 1 & & & & & & & & & & & 1 \\
\hline Fabaceae (large) & & 3 & & & 2 & 2 & 3 & 2 & & & & & & & & & & 14 \\
\hline Fabaceae (small) & & & 1 & & & & & & & & & & & & & & & 1 \\
\hline Galium sp. & & & & & & & & & & & & & & & & & & 1 \\
\hline Lolium sp. & & & & & & & & & & & & & & & 1 & & & 1 \\
\hline Lolium temulentum & & & & & & & & & & & & & & 1 & & & & 1 \\
\hline Phleum sp. & & & & & & & & 1 & & & & & & & & & & 1 \\
\hline Poaceae (large) & & & & & 5 & & 2 & & & & & & & & & & & 10 \\
\hline Poaceae (small) & & & 1 & & 4 & & & 1 & & & 4 & & & & & & & 11 \\
\hline cf. Polygonum sp. & & & & & & 1 & & & & & & & & & & & & 1 \\
\hline Quercus sp. & & & & & & 1 & (1) & & & & & & & & & & & $1(1)$ \\
\hline Rosa canina & & 1 & & & & & & & & & & & & & & & & 1 \\
\hline Rubus sp. & & & & & & & & 1 & & & & & & & & & & 1 \\
\hline Rumex sp. & & & & & & & & & & & 1 & & & & & & 1 & 3 \\
\hline Sambucus ebulus & & & & & & & 1 & & & & & & & & & & & 1 \\
\hline Teucrium sp. & & & & 1 & & & & & & & & & & & & & & 1 \\
\hline Verbascum sp. & & & & & & 1 & & & & & & & & & & & & 1 \\
\hline Indeterminate fruit & & & & & 3 & & & & & & & & & & & & & 3 \\
\hline Indeterminate & & & 9 & 11 & 113 & 19 & $\mid 180$ & 300 & 26 & 22 & 4 & 1 & 2 & 2 & & 48 & 12 & 973 \\
\hline
\end{tabular}

\section{Tab. 3. continued}

more susceptible to increased moisture in the atmosphere and to fungal attack (Van der Veen 1992.74).

In the archaeobotanical results at Velištak, barley dominates the crop remains, accounting for $94 \%$ of the cereals. As already discussed, sample no. 185 (lower half of a pit fill) contained 752 barley grains, but very few other plant remains, although over 1000 cereal grain fragments were also identified. Due to poor preservation, most of the grains could not be identified as either hulled or naked varieties, but many did have the more rounded shape of naked barley, while a couple were more angular, characteristic of hulled barley. A few grains also had the characteristic lateral twist of six-rowed barley (Zohary et al. 2012.56). Thus, poor preservation prevents further discussion as to the preference for hulled or naked barley growing at Velištak from the current assemblage.

Apart from this pit feature (samples nos. 179, 180, $184,185)$, the quantity of barley, emmer and einkorn grains is the same, suggesting that barley may not have been the main 'preferred' crop at the site.
This is further supported by the relatively high number of glume wheat glume bases seen in samples nos. 49 and 258. The ratio of cereal species may therefore indicate differences in preservation rather than the predominance of barley at the site.

\section{Plant economies of the Hvar culture}

The entire area of the Eastern Adriatic, from the Trieste Karst in the north to the Gulf of Kotor in the south, is characterised by alternating dry barren karst landscapes, sunken karst fields and ridges, limestone plateaus and fertile valleys filled with springs, underground streams and gorges (Magaš 1998.195). Within this landscape, early Neolithic occupation seems to have clustered in three main areas: one cluster of cave and open-air settlements in coastal Istria and the Kvarner islands, a second cluster of open-air settlements in the Zadar and Šibenik area, and a third cluster of cave sites to the south in the Pelješac peninsula and within the hinterlands of Herzegovina (Marijanovic 2007). The fertile valleys of the Zadar/Šibenik area, and the fact that most of the archaeobotanical evidence has been 
recovered from this region, has led researchers to believe that this area provided the best conditions for Neolithic crop agriculture (e.g., Brusić 2008.6364). In contrast, the cave sites are located in mountainous areas away from land suitable for agriculture, and are usually interpreted as seasonal herding camps, marked by low density pottery and animal bone finds (e.g., Miracle, Forenbaher 2005; Mlekuž 2005). This is probably the case at Turska Peć, where the archaeobotanical remains identified an area resulting from human activities (where cereal remains were recovered) and an area that was probably subject to the periodic burning of animal dung (where wild, weed species were recovered) (Reed 2015). An exception to this is Grapčeva, where the large number of animal remains, artefacts and scattered human remains suggests ritual activities, where feasts, offerings and secondary burials took place (Forenbaher, Kaiser 2008; Forenbaher et al. 2010).

Therefore, the three late Neolithic sites present archaeobotanical remains from a ritual context, a possible herding camp and a valley settlement. Although they cannot be directly compared, as bias in the range of plant remains found in such locations will be present, we can begin, if only tentatively, to reconstruct the plant economies of the late Neolithic period in the Eastern Adriatic. For example, emmer, einkorn, and barley are the most common cereals identified from the three sites. This corresponds with archaeobotanical evidence from northern Italy (Rottoli 2014.76), Slovenia (Tolar et al. 2011), and continental Croatia (Reed 2015) and would suggest that these were the main cereals grown at the time. Evidence of naked wheat, spelt, rye, and millet is sporadic, so it is unlikely that they were grown as part of the crop package during the late Neolithic in this region. Unfortunately, the general low density of plant remains at Velištak also means that the analysis of samples in relation to cultivation methods (i.e. whether crops were manured, weeded, etc.) is not possible at present. Other crops were also probably grown, including pulses, such as lentil, pea and flax. The recovery of cornelian cherry seeds (Cornus mas), brambles (Rubus sp.), oak (Quercus sp.), dog rose (Rosa canina), and dwarf elder (Sambucus ebulus) suggests that local woodland and woodland fringes were exploited by the inhabitants of Velištak to supplement the diet.

Compared to the earlier Neolithic, the plant spectra in coastal Croatia does not seem to change, with the main founder crops - emmer, einkorn, barley, lentil, pea, and flax - being found throughout the Neolithic (Reed 2015). Although naked wheat (Triticum $d u$ rum/turgidum/aestivum) has also been discovered at the early Neolithic site of Tinj-Podlivade (Huntley 1996), the middle Neolithic site of Danilo-Bitinj (Reed 2006), and late Neolithic levels at Grapčeva cave (Borojevic et al. 2008), it is unlikely that the few grains recovered, as well as the single grain from Velištak, means it was cultivated during the Neolithic in the Eastern Adriatic.

\section{Conclusion}

The analysis of carbonised plant remains from Velištak presents the first archaeobotanical evidence from an open-air settlement dating to the late Neolithic Hvar culture in the Eastern Adriatic. The formation processes inferred from the plant remains suggest that they probably resulted from a number of charring events that were then discarded as secondary or tertiary deposits. The only possible exception to this was the recovery of a relatively large deposit of barley grains in the bottom of a pit feature. The remains are probably from a barley crop that were carbonised and, as there was very little sign of burning in the pit, dumped as waste. The remains of a relatively high number of glume wheat (Triticum monococcum/turgidum ssp. dicoccum/'new-type' glume wheat) glume bases within a pit a few metres away also suggests that crop processing of glume wheats occurred at the site, probably within the home where the by-products could be easily thrown into the hearth and then re-deposited within the pit as waste. Thus the results from the 2007 to 2013 field seasons suggest that emmer, einkorn and barley were grown as the main crops at Velištak, along with lentil, bitter vetch and possibly pea and flax. However, further work is clearly needed in recovering archaeobotanical remains from late Neolithic sites in order to understand more fully the development of subsistence economies in the Eastern Adriatic. 


\section{References}

Benac A. 1958. Neolitsko naselje u Lisičicima kod Konjica. Djela X. Naučno društvo Bosne i Hercegovine. Sarajevo.

Behre K.-E. 1992. The history of rye cultivation in Europe. Vegetation History and Archaeobotany 1: 141-156.

Boardman S., Jones G. 1990. Experiments on the effects of charring on cereal plant components. Journal of Archaeological Science 17(1): 1-11.

Bogaard A. 2004. Neolithic Farming in Central Europe: An Archaeobotanical Study of Crop Husbandry Practices. Routledge. London.

Bogucki P. 1996. The spread of early farming in Europe. American Science 84: 242-253.

Bonsall C., Tolan Smith C. (eds.) 1997. The Human Use of Caves. British Archaeological reports IS 667. Archaeopress. Oxford.

Borojević K., Forenbaher S., Kaiser T. and Berna F. 2008. Plant use at Grapčeva cave and in the eastern Adriatic Neolithic. Journal of Field Archaeology 33(3): 279-303.

Brusić Z. 2008. Pokrovnik, naselje iz neolitika. Muzej grada Šibenika. Šibenik.

Ceccarelli S., Grando S., Bailey E., Amri A., El-Felah M., Nassif F., Rezgui S. and Yahyaoui A., 2001. Farmer participation in barley breeding in Syria, Morocco and Tunisia. Euphytica 122(3): 521-536.

Chapman J. 1988. Ceramic production and social differentiation: the Dalmatian Neolithic and the Western Mediterranean. Journal of Mediterranean Archaeology 1(2): 3-25.

Chapman J. C., Müller J. 1990. Early Farmers in the Mediterranean Basin: The Dalmatian Evidence. Antiquity 64: 127-134.

Charles M. 1998. Fodder from dung: the recognition and interpretation of dung derived plant material from archaeological sites. Environmental Archaeology 1: 111-122.

Davison K., Dolukhanov P., Sarson G. R. and Shukurov A. 2006. The role of waterways in the spread of the Neolithic. Journal of Archaeological Science 33: 641-652.

Dennell R. W. 1972. The interpretation of plant remains: Bulgaria. In E. S. Higgs (ed.), Papers in Economic Prehistory. Cambridge University Press. Cambridge.

1974. The purity of prehistoric crops. Proceedings of the Prehistoric Society 40: 132-135.
1976. The economic importance of plant resources represented on archaeological sites. Journal of Archaeological Science 3: 229-247.

Filipović D., Obradović Đ. 2013. Archaeobotany at Neolithic Sites in Serbia: A Critical Overview of the Methods and Results. In N. Miladinović-Radmilović, S. Vitezović (eds.), Bioarheologija na Balkanu: bilans i perspektive. Srpsko Arheološko Društvo. Beograd: 25-55.

Forenbaher S., Kaiser T. (eds.) 2008. Grapčeva špilja: pretpovijesni stan, tor I obredno mjesto. Rezultati arheološkog istraživanja 1996. godine. Književni krug. Split.

Forenbaher S., Miracle P. T. 2005. The spread of farming in the eastern Adriatic. Antiquity 79(305): 514-528.

Forenbaher S., Kaiser T. and Frame S. 2010. Adriatic Neolithic Mortuary Ritual at Grapčeva Cave, Croatia.Journal of Field Archaeology 35(4): 337-354.

Forenbaher S., Kaiser T. and Miracle P. T. 2013. Dating the East Adriatic Neolithic. European. Journal of Archaeo$\log y$ 16(4): 589-609.

Gjipali I., Allen S. 2013. Investigations on the Early Neolithic Period in Albania: Vashtëmi. In I. Gjipali., L. Perzhita and B. Muka (eds.), Recent Archaeological Discoveries in Albania. Centre for Albanian Studies. Institute of Archaeology. Tirana: 22-25.

Gnirs A. 1925. Istria Praeromana. Beiträge sur Geschichte der frühesten und vorrömischen Kulturen an den Küsten der Nördlichen Adria. Mit Unterstützung des Ministeriums für Schulwesen und Volkskultur. Verlag von Walther Heinisch. Karlsbad.

Gregg S. 1989. Paleo-ethnobotany of the Bandkeramik phases. In C. Kind (ed.), Ulm-Eggingen: Die Ausgrabungen 1982 bis 1985 in der bandkeramischen Siedlung und der mittelalterlichen Wüstung. Forschungen und Berichte zur Vor- und Frühgeschichte in Baden-Württemberg 34. Konrad Theiss Verlag. Stuttgart: 367-399.

Gyulai F. 2010. Archaeobotany in Hungary: Seed, Fruit, Food and Beverage Remains in the Carpathian Basin from the Neolithic to the Late Middle Ages. Archaeolingua. Budapest.

Hillman G. C. 1981. Reconstructing crop husbandry practices from the charred remains of crops. In R. Mercer (ed.), Farming Practice in British prehistory. Edinburgh University Press. Edinburgh: 123-162.

1984. Interpretation of archaeological plant remains: application of ethnographic models from Turkey. In W. A. Casparie, W. van Zeist (eds.), Plants and Ancient 
Man: Studies in palaeoethnobotany. Balkema. Rotterdam: 1-41.

Hopf M. 1958. Neolitische Getreidefunde aus Bosnien und der Hercegovina. Glasnik Zemaljskog Muzeja u Sarajevu 13: 97-103.

1964. Untersuchung der Getreidereste im Hüttenlehm aus Danilo. In J. Korošec (ed.), Danilo in danilska kultura. Univerzitetna založba. Ljubljana: 107-108.

1966/1967. Untersuchungen über die botanischen Reste aus der neolitischen Ansiedlung in Gornja Tuzla. Glasnik Zemaljskog Muzeja u Sarajevu N.S. 21/22: 169171.

Hubbard R. N. L. B., Clapham A. 1992. Quantifying macroscopic plant remains. Review of Palaeobotany and Palynology 73: 117-132.

Huntley J. 1996. The plant remains. In J. Chapman., R. Shiel and Š. Batović (eds.), The Changing Face of Dalmatia. Leicester University Press. Leicester: 187-189.

Jones G. 1981. Crop processing at Assiros Toumba: a taphonomic study. Zeitschrift für Archäologie 15: 105-111.

1984. Interpretation of archaeological plant remains: ethnographic models from Greece. In W. A. Casparie, W. van Zeist (eds.), Plants and Ancient Man: Studies in palaeoethnobotany. Balkema. Rotterdam: 43-61.

1991. Numerical analysis in archaeobotany. In W. van Zeist., K. Wasylikowa and K. E. Behre (eds.), Progress in Old World palaeoethnobotany. Balkema. Rotterdam: 63-80.

Jones G., Valamoti S., Charles M. 2000. Early crop diversity: a "new" glume wheat from northern Greece. Vegetation History and Archaeobotany 9: 133-146.

Karg S., Müller J. 1990. Neolithische Getreidefunde aus Pokrovnik, Dalmatien. Archäologisches Korrespondenzblatt 20: 373-386.

Knörzer K. H. 1971. Urgeschichtliche unkräuter im Rheinland ein beitrag zur entstehungsgeschichte der segetal gesellschaften. Vegetatio 23(1-2): 89-111.

Kohler-Schneider M. 2003. Contents of a storage pit from Late Bronze Age Stillfried, Austria: another record of the "new" glume wheat. Vegetation History and Archaeobotany 12(2): 105-111.

Komšo D. 2005. Kargadur. In J. Mesić (ed.), Hrvatski arheološki godišnjak. 2. Ministarstvo Kulture. Zagreb: 212214.
Kreuz A. 2012. Die Vertreibung aus dem Paradies? Archäobiologische Ergebnisse zum Frühneolithikum im westlichen Mitteleuropa. Bericht der Römisch-Germanischen Kommission 91: 23-196.

Kreuz A., Boenke N. 2002. The presence of two-grained einkorn at the time of the Bandkeramik culture. Vegetation History and Archaeobotany 11(3): 233-240.

Kroll H. 1992. Einkorn from Feudvar, Vojvodina, II. What is the difference between emmer-like two-seeded einkorn and emmer? Review of Palaeobotany and Palynology 73(1-4): 181-185.

Kučan D. 2009. Preliminarni izvještaj o ispitivanjima ugljenisanih biljnih ostataka na kasnoneolitskom naselju okolište. In R. Hofmann., Z. Kujundžic-Vejzagic., J. Müller, K. Rassmann and N. Müller-Scheeßel (eds.), Rekonstrukcija procesa naseljavanja u kasnom neolitu na prostoru centralne Bosne. Glasnik Zemaljskog muzeja Bosne i Hercegovine u Sarajevu 50/51. Sarajevo: 127-131.

Legge A., Moore A. 2011. Clutching at straw: the Early Neolithic of Croatia and the dispersal of agriculture. In A. Hadjikoumis., E. Robinson and S. Viner (eds.), The Dynamics of Neolithisation in Europe: Studies in Honor of Andrew Sherratt. 0xbow Books. Oxford: 176-95.

Lightfoot E., Boneva B., Miracle P. T., Šlaus M. and O'Connell T. C. 2011. Exploring the Mesolithic and Neolithic transition in Croatia through isotopic investigations. $\mathrm{An}$ tiquity 85(327): 73-86.

Lister D. L., Jones M. K. 2013. Is naked barley an eastern or a western crop? The combined evidence of archaeobotany and genetics. Vegetation History and Archaeobotany 22(5): 439-446.

Magaš D. 1998. Osnove geografije Hrvatske. Filozofski fakultet Zadar. Odsjek za geografiju. Zadar.

Marijanović B. 2007. Neka pitanja ranog neolitika istočnog Jadrana. Archaeologia Adriatica 1: 7-54.

McClure S., Podrug E., Moore A. M. T., Culleton B. J. and Kennett D. J. 2014. AMS ${ }^{14} \mathrm{C}$ Chronology and Ceramic Sequences of Early Farmers in the Eastern Adriatic. Radiocarbon 56(3): 1019-1038.

Meurers-Balke J., Lüning J. 1992. Some aspects and experiments concerning the processing of glume wheats. In P. C. Anderson (ed.), Prehistoire de l'Agriculture: Nouvelles Approches Experimentales et Ethnographiques. Monographie du CRA 6. Éditions du Centre national de la recherche scientifique. Paris: 341-362.

Miller N., Smart T. 1984. Intentional burning of dung as fuel: a mechanism for the incorporation of charred seeds 
into the archaeological record. Journal of Ethnobiology $4(1): 15-28$.

Miracle P. T., Forenbaher, S. 2005. Neolithic and BronzeAge herders of Pupicina Cave, Croatia. Journal of Field Archaeology 30: 255-281.

Mlekuž D. 2005. The ethnography of the Cyclops: Neolithic pastoralists in the eastern Adriatic. Documenta Praehistorica 32: 15-51.

Moore A., Menđušić M. and Smith J. 2007a. Project "Early farming in Dalmatia": Danilo Bitinj 2004-2005. Vjesnik Arheološkog muzeja u Zagrebu 40: 15-24.

Moore A., Menđušić M., Smith J., Podrug E. and Zaninović J. 2007b. Project "Early farming in Dalmatia": Pokrovnik 2006. Vjesnik Arheološkog muzeja u Zagrebu 40: 25-34.

Müller J. 1994. Das Ostadriatische Frühneolithikum: Die Impresso Kultur und die Neolithisierung des Adriaraumes. Volker Spiess. Berlin.

Novak G. 1955. Prethistorijski Hvar: Grapčeva spilja. Jugoslavenska akademija znanosti i umjetnosti. Zagreb.

Podrug E. 2010. Čista Mala - Velištak: prve tri istraživačke kampanje na nalazištu hvarske kulture/ Čista Mala Velištak: The first three excavation campaigns at a Hvar culture site. Diadora 24: 7-25.

2013. Neolithic immovable finds in the Sibenik area. Diadora 26/27: 185-212.

2014. Velištak. In P. Visentini and E. Podrug (eds.), Adriatico senza confini: via di comunicazione e crocevia di popoli nel 6000 a. C./ The Adriatic, a sea without borders: communication routes of populations in 6000 BC. Civici Musei di Udine - Museo Friulano di Storia Naturale. Udine: 84-85.

Reed K. 2006. Early Farming in Dalmatia: Preliminary Archaeobotanical Report on the Middle Neolithic site of Danilo. Unpublished MSc thesis. Institute of Archaeology. University College London. London.

2015. From the Field to the Hearth: plant remains from Neolithic Croatia (ca. 6000-4000 cal BC). Vegetation History and Archaeobotany 24(5): 601-619.

Renfrew J. 1979. The first farmers of south east Europe. Archaeo-Physika 8: 243-265.

Robb J. 2007. The Early Mediterranean Village: Agency, Material Culture and Social Change in Neolithic Italy. Cambridge University Press. Cambridge.

Rottoli M. 2014. Crop diversity between Central Europe and the Mediterranean: aspects of northern Italian agri- culture. In A. Chevalier., E. Marinova and L. Peña-Chocarro (eds.), Plants and People: Choices and Diversity through Time. Oxbow. Oxford: 75-81.

Rottoli M., Castiglioni E. 2009. Prehistory of plant growing and collecting in northern Italy, based on seed remains from early Neolithic to the Chalcolithic (c. 5600-2100 cal B.C.). Vegetation History and Archaeobotany 18: 91103.

Rottoli M., Pessina A. 2007. Neolithic agriculture in Italy: an update of archaeobotanical data with particular emphasis on Northern settlements. In S. Colledge and J. Connolly (eds.), Origins and spread of domesticated plants in Southwest Asia and Europe. Left Coast Press. Walnut Creek: 141-153.

Sampson A. 2008. The Cave of the Cyclops: Mesolithic and Neolithic networks in the Northern Aegean, Greece. Vol. 1, Intra-Site Analysis, Local Industries, and Regional Site Distribution. INSTAP Academic Press. Philadelphia.

Šoštarić R. 2009. Karbonizirani ostatci žitarica - tragovi poljodjelstva. In B. Marijanović (ed.), Crno Vrilo 2. Sveučilište u Zadru. Zadar: 49-52.

Spataro M. 2002. The First Farming Communities of the Adriatic: Pottery Production and Circulation in the Early and Middle Neolithic. Società per la Preistoria e Protostoria della Regione Friuli-Venezia Giulia. Quaderno 9. Trieste.

Tolar T., Jacomet S., Velušček A. and Čufar K. 2011. Plant economy at a late Neolithic lake dwelling site in Slovenia at the time of the Alpine Iceman. Vegetation History and Archaeobotany 20(3): 207-222.

Trantalidou K., Belegrinoy E. and Andreasen N. 2010. Pastoral societies in southern Balkan peninsula: the evidence from caves occupied during the Neolithic and Chalcolithic era. ANODOS, studies of ancient world 10: 321334 .

Tutin T. G., Heywood V. H., Burges N. A., Moore D. M., Valentine D. H., Walters S. M. and Webb D. A. 1964-1980. Flora Europaea. Vols. 1-5. Cambridge University Press. Cambridge.

Valamoti S. M., Charles M. 2005. Distinguishing food from fodder through the study of charred plant remains: an experimental approach to dung-derived chaff. Vegetation History and Archaeobotany 14(4): 528-533.

Van der Veen M. 1992. Crop Husbandry Regimes: An Archaeobotanical Study of Farming in northern England $1000 B C-A D$ 500. J. R. Collis Publications. Sheffield.

2007. Formation processes of desiccated and carbonized plant remains - the identification of routine prac- 
tice. Journal of Archaeological Science 34(6): 968990.

Van der Veen M., Jones G. 2006. A re-analysis of agricultural production and consumption: Implications for understanding the British Iron Age. Vegetation History and Archaeobotany 15(3): 217-228.

Xhuveli L., Schultze-Motel J. 1995. Neolithic cultivated plants from Albania. Vegetation History and Archaeobotany 4: 245-248.
Zavodny E., McClure S. B., Culleton B. J., Podrug E. and Kennett D. J. 2014. Identifying Neolithic animal management practices in the Adriatic using stable isotopes. Documenta Praehistorica 42: 261-274.

Zohary D., Hopf M. and Weiss E. 2012. Domestication of plants in the Old World: the origin and spread of domesticated plants in south-west Asia, Europe, and the Mediterranean Basin. Oxford University Press. Oxford. 